\title{
HIBRIDITAS TOKOH DALAM NOVEL REMAJA KERONCONG CINTA KARYA AHMAD FAISHAL
}

\author{
Dheny Jatmiko \\ Universitas 17 Agustus 1945 Surabaya
}

\begin{abstract}
Abstrak
Novel Keroncong Cinta karya Ahmad Faishal merupakan novel remaja yang menceritakan kehidupan sosial, politik, dan budaya sebuah keluarga karena perkawinan antarras Eropa-Jawa di akhir masa kolonial. Penelitian ini memanfaatkan pendekatan poskolonial untuk mengungkap bentuk-bentuk hibriditas tokoh dan diinterpretasi dalam kaitannya dengan konteks masa kolonial di Hindia Belanda. Penelitian ini menemukan bahwa hibriditas di Hindia Belanda disebabkan oleh perkawinan, pergundikan, pendidikan, dan semangat memperoleh persamaan derajat yang dialami kalangan Indo. Bentuk-bentuk hibriditas tokoh ditunjukkan dengan adanya ambivalensi dan ambiguitas identitas sebagai akibat dari kontradiksi antara kultur Eropa dan pribumi. Bentukbentuk hibriditas tokoh antara lain ambiguitas identitas dan kesadaran orang Indo sebagai kelas ketiga;pengaburan garis-garis kontradiktif koloniaslisme; dan orientasi ke-Eropa-an seorang Nyai. Penelitian ini sekaligusmembuktikan bahwa sastra remaja, sebagai bagian sastra populer, bukan hanya sastra yang berisi hiburan dan kesederhanaan.
\end{abstract}

Kata kunci: kolonialisme, bibriditas, ambiguitas, identitas

\begin{abstract}
The novel Keroncong Cinta by Ahmad Faishal was an adolescent novel about social, politics and culture life of a family due to the interracial Europe-Java marriage at the end of colonial era. This research used postcolonial approach to reveal the forms of characters hybridity and interpret it in relation to the colonial era in Dutch East Indies context. This research discovered that the hybridity in Dutch East Indies caused by marriage, concubinage, education and the spirit to gain equality experienced by the Indo. The forms of characters bybridity showed through the identity ambivalence and ambiguity as the results of contradiction between indigenous and Europe cultures. These forms among others are identity ambiguity and awareness of the Indo as the third class, the blurring of colonialism contradictive lines and a lady's Europe orientation. This research also proofed that adolescent literatures, as a part of popular literatures, are not only literatures filled with entertainment and simplicity.
\end{abstract}

Keywords: colonialism, bybridity, ambiguity, identity 


\section{PENDAHULUAN}

Kajian ini mengambil novel Keroncong Cinta karya Ahmad Faishal (2006) sebagai objek material. Novel Keroncong Cintamerupakan salah satu novel unggulan dalam Sayembara Mengarang Novel Remaja 2005 yang diadakan oleh Grasindo dan Radio Nederland Ranesi. Di sampul belakang novel, penerbit (Grasindo) memberikan catatan akhir (endorsement) sekaligus bentuk pelabelan terhadap novel Keroncong Cinta, yaitu "Nikmati rasa baru novel remaja lewat cerita ini". Dengan demikian, novel Keroncong Cinta dapat dimasukkan ke dalam kategori sastra remaja.

Sastra remaja merupakan bagian dari sastra populer. Dalam kerangka pembagian sastra menurut Heryanto (1988: 4-7) disebutkan bahwa terdapat sastra yang "diremehkan", yaitu sastra populer. Sastra populer juga menjadi salah satu alternatif produksi sastra yang dianggap aman dari perhatian pemerintah Orde Baru. Salam (2002: 207) berpendapat bahwa fiksi populer yang semakin marak pada tahun 1970-an hingga awal 1980-an menjadi bagian tersendiri bagi masyarakat Indonesia untuk melakukan semacam "pelarian" dari wacana politik yang demikian ketat, atau justru sebagai ajang kompromi imajinari terhadap realitas politik yang sesungguhnya. Fiksi populer tidak hanya diabaikan peneliti, tetapi juga secara sukarela dibiarkan oleh kekuasaan karena dianggap tidak mengganggu, dalam beberapa hal justru melegitimasi kekuasaan yang sedang berlangsung, mengusung wacana-wacana dominan yang justru memperkuat posisi elite.

Inti dari sastra populer adalah hiburan. Karya sastra diciptakan untuk memberikan hiburan bagi pembacanya. Sastra populer menghadirkan cerita-cerita yang ringan, dengan plot yang konvensional, dan dengan bahasa yang mudah dimengerti. Sumarjo (1982: 23) menyebut sastra populer hanya pandai menyajikan kisah-kisah yang menawan, sementara ide, pemikiran tentang kehidupan dianggap mudah belaka. Sumarjo (1982: 22) juga menjelaskan bahwa sastra populer bersifat temporer, berbeda dengan sastra besar yang mengejar sifat universal dan abadi. Hal ini dipengaruhi oleh selera publik (pembaca). Oleh karena itu, dalam sastra populer terjadi reproduksi karya-karya yang sejenis dan setipe dalam jumlah yang besar untuk memenuhi kebutuhan pasar.

Tentang perbedaan antara sastra serius dan populer, Gelder (2004: 19) menyebutkan bahwa sastra serius menunjukkan kompleksitas, sedangkan sastra populer lebih pada kesederhanaan. Keduanya menawarkan kenikmatan dengan karakteristik yang khas, artinya bahwa pengalaman yang didapat ketika membaca sastra 'serius' akan jauh berbeda jenisnya dengan pengalaman membaca sastra populer. Sastra serius lebih erat kaitannya dengan kehidupan, sedangkan sastra populer lebih pada fantasi. Hal senada juiga dikemukakan oleh Kayam (1981: 88) bahwa sastra populer merupakan perekam kehidupan yang tidak banyak membincangkan kembali dalam serbakemungkinan. Penulis sastra populer memilih rekaman tentang kehidupan, menyajikan kembali, dengan perhitungan pembacanya akan banyak mengenal kembali pengalaman-pengalamannya hingga terhibur. Adapun sastra yang 'sastra' atau sastra 'serius' (untuk menyebut sastra luhur) tidak sekedar merekam kembali, tetapi membincangkan kembali melalui manipulasi, dan rasa sastra.

Sementara itu, novel Keroncong Cinta dengan label sastra remaja justru menunjukkan kecenerungan yang berbeda. Keroncong Cintamerupakan novel yang menggunakan sejarah sebagai penggerak utamanya, yang secara implisit dijelaskan bahwa peristiwa dalam novel terjadi pada tahun 1930-1942, saat Indonesia berada di akhir masa kolonialisasi Belanda dan awal masuknya Jepang. Kolonialisasi menciptakan konstruksi yang harus dihadapi oleh kolonis, baik mengikuti ataupun menentangnya. Keroncong Cinta memunculkan efek dari kolonialisasi yang berkepanjangan di Indonesia, yaitu percampuran kebudayaan yang mengakibatkan adanya pembentukan identitas dan status sosial baru pada tokoh-tokoh. Namun, ketika dominasi bangsa Eropa (Belanda) diruntuhkan oleh Jepang, kembali terjadi perubahan-perubahan kebijakan yang berimbas pada perubahan nasib dan status, terutama pada tokoh-tokoh indo (keturunan Eropa).

Keroncong Cinta merepresentasikan pembentukan karakter tokoh-tokoh sebagai hasil dari percampuran antara kebudayaan Barat (Belanda) dan Timur (Jawa) dalam dominasi dan hegemoni kolonial Belanda. Hibriditas tokohtokoh disertai kemunculan sikap-sikap yang ambivalen menjadikan posisi tokoh berada dalam posisi 'antara' dua wilayah yang selalu kontradiktif. Batas-batas kebudayaan yang mapan dikaburkan dan dibuat tidak stabil oleh hibridasi. Dalam menghadapi ketidakstabilan budaya, sebagaimana dikatakan Homi Bhaba (dalam Kasiyan, 2003:80), memaksa untuk tidak memikirkan kebudayaan dan 
identitas sebagai entitas yang bersifat tetap, dan selalu berubah.

Membaca novel Keroncong Cinta seperti diajak kembali untuk "berwisata" sejarah. Kolonialisme dan hibriditas menjadi kunci utama. Dengan mengambil latar kota Surabaya tahun 1930-1942, jejak-jejak kolonial dapat ditemukan dan digarap secara mendetail. Hibriditas tidak hanya muncul dan dialami oleh tokoh-tokoh keturunan (indo), namun terdapat juga tokohtokoh dari golongan lain, seperti Belanda totok dan pribumi. Hal ini dikarenakan hibriditas tercipta dari beberapa hal antara lain perkawinan antara orang kolonial Belanda dengan pribumi, pergundikan, produk pendidikan Eropa, dan semangat meraih persamaan derajat seperti yang dialami oleh kalangan Indis.

Berdasar uraian di atas, penelitian ini menitikberatkan pada tokoh-tokoh yang mengalami hibriditas dan sikap yang ambivalen. Fokus utama penelitian ini adalah bagaimana pembentukan karakteristik tokoh-tokoh hibrida dalam menghadapi kondisi yang ada. Teori poskolonial menjadi teori yang paling relevan untuk mengkaji permasalahan tersebut. Pada dasarnya poskolonial adalah sebuah upaya penggalian yang lebih sederhana atas ingataningatan yang tidak mengenakkan, berupaya mengungkap kekerasan kolonisasi yang melimpah dan masih tersisa. Penelitian ini sekaligus juga berusaha membuktikan bahwa sastra remaja, sebagai bagian sastra populer, bukan hanya sastra yang berisi hiburan dan kesederhanaan.

\section{LANDASAN TEORI}

Penelitian ini memanfaatkan teoriposkolonial untuk membedah dan menginterpretasi tokohtokoh hibrida. Istilah poskolonial seringkali ditulis dengan pascakolonial, namun kedua istilah ('pos' dan 'pasca') tersebut memiliki substansi yang sama, merupakan bentuk terikat dari yang sebelumnya, kolonial. Hal ini diperkuat dengan penulisan 'poskolonial' yang tidak memakai tanda hubung. Menurut Gandhi (2006:4), sebagian kritikus menyatakan bentuk 'poskolonial' dengan tanda hubung sebagai penanda temporal yang menentukan proses dekolonisasi, kritikus lain mempertanyakan pemisahan kronologis yang diimplikasikan antara kolonialisme dan akibatnya-karena alasan-alasan bahwa kondisi poskolonial diawali dengan serangan (onset) ketimbang berakhirnya pendudukan kolonial. Oleh karenanya, istilah 'poskolonial' yang tak terpisah (tanpa tanda hubung) jauh lebih sensitif terhadap sejarah panjang pelbagai konsekuensi kolonial.

Gandhi (2006:5) menjelaskan bahwa teori poskolonial merupakan upaya untuk memahami kondisi kesejarahan yang partikular. Teori inilah yang disebut sebagai 'poskolonialisme' dan kondisi yang dirujuknya disebut dengan 'poskolonialitas'. Poskolonialisme dapat dilihat sebagai resistensi teoretis terhadap amnesia yang membingungkan akibat penjajahan. Jika poskolonialitas dapat digambarkan sebagai suatu kondisi yang terganggu oleh konsekuensi-konsekuensi dari amnesia historis berswakehendak (self-willed) maka nilai teoretis poskolonialisme terletak, sebagian, pada kemampuannya untuk mengelaborasi memorimemori yang terlupakan atas kondisi ini (Gandhi, 2006:10). Teori poskolonial adalah sebuah proyek disiplineryang dicurahkan untuk menunaikan tugas akademik guna menilik ulang, mengingat-ingat dan, secara krusial, menyelidiki masa lalu kolonial. Kontoversi apa pun yang terjadi di seputar teori ini, nilainya harus dilihat dalam kemampuannya untuk mengkonseptualkan kondisi kompleks yang menyertai akibat buruk pendudukan kolonial.

Menurut Bhaba (dalam Gandhi, 2001:1314), pengenangan teoretis atas kondisi kolonial dilakukan untuk memenuhi dua fungsi. Pertama, sebagai penggalian yang lebih sederhana atas ingatan-ingatan yang tidak mengenakkan, berupaya mengungkap kekerasan kolonisasi yang melimpah dan masih tersisa. Kedua, pendamaian dalam usahanya untuk membuat masa lalu yang bermusuhan dan antagonistik menjadi lebih ramah dan oleh karena itu lebih mudah didekati. Peristiwa dalam kolonialisasi selalu terekam dalam ingatan kalangan terjajah dan menjadi kenangan yang tidak pernah terlupakan. Justru inilah yang dimaksud Gandhi sebagai nilai teoretis poskolonislisme, seperti pada penjelasan di atas, yaitu pada kemampuannya untuk mengelaborasi memori-memori yang terlupakan atas kondisi kolonial.

Teori poskolonial dalam hubungannya dengan sastra, dimanfaatkan untuk membedah teks sastra poskolonial dan melacak kembali jejak-jejak kolonialyang terseimpan dalam teks tersebut. Lebih lanjut Foulcher dan Day (2006:3), menjelaskan bahwa poskolonialisme dalam pengkajian sastra dipandang sebagai sebuah strategi kritik yang mengajukan pertanyaan-pertanyaan yang bisa melacak jejak-jejak kolonialisme dalam teks sastra maupun kritik sastra, juga mengevaluasi sifat 
dan efek-efek tekstual dari jejak-jejak tersebut. Oleh karena itu, pendekatan poskolonial dalam teks sastra merupakan pergulatan yang berusaha mengungkapkan bekas-bekas pertemuan kolonial, konfrontasi ras, dan kondisi hubungan-hubungan kekuasaan tak setara. Terdapat kesepakatan kecil tentang korban-korban terburuk penindasan kolonial atau tentang pemberontakanpemberontakan antikolonial yang paling signifikan.

Bill Ashcroff, dkk. (dalam Gandhi, 2006: vi-vii) dalam The Empire Writes Back (1989) menunjukkan adanya dua model penting dalam sastra poskolonial, yaitu model nasional dan model black writing. Model nasional memusatkan perhatiannya pada hubungan antara negara dan bekas-bekas jajahannya, sedangkan model black writing lebih menitikberatkan pada aspek etnisitas ketimbang nasionalitas. Selanjutnya, Aschroff, dkk. menunjukkan bahwa sastra dan teori poskolonial memiliki kunci utama, yaitu dominasisubordinasi dan hibriditas-kreolisasi.Dominasi dan subordinasi adalah sebuah hubungan yang tidak hanya terjadi antar negara atau antar etnis, tetapi dalam sebuah negara atau dalam etnis tertentu. Hibriditas mengacu pada suatu penciptaan format-format transkultural baru dalam zonahubung produk kolonialisasi (Gandhi, 2006:viii), sedangkan kreolisasi menurut Barker (2005:291), menekankan bahwa bahasa sebagai praktik budaya dan penemuan langgam ekspresi baru yang khas bagi dirinya sendiri. Selanjutnya, penjelasan lebih difokuskan tentang konsep hibriditas, yang sekaligus menjadi fokus penelitian ini.

Hibriditas menurut Bhaba (dalam Lym, 2006), dalam wacana kolonial, mengacu pada "suatu problema representasi dan individuasi kolonial, yang membalikkan dampak-dampak penyangkalan kolonial, sedemikian rupa sehingga pengetahuan lain yang disangkal meresap ke dalam wacana dominan dan mengasingkan pijakan kewenangannya-kaidah pengakuannya. Hibriditas dapat dipahami, sebagai narasi perlawanan, sebuah kritik terhadap narasi utama (kanon) dan juga kritik terhadap peminggiran narasi yang lain.

Hibriditas muncul dari sifat sinkretik masyarakat, budaya, dan wacana poskolonial (Gandhi, 2006:ix). Lebih lanjut, Gandhi (2006:ix) menjelaskan bahwa hibriditas adalah sebuah perjuangan untuk mencari jalan alternatif yang sama validnya dengan wacana dominan, berupaya memperjuangkan terbentuknya semacam "budaya ketiga" yang sama validnya dengan budaya kolonial-dominan. Hal ini yang membedakan hibriditas dengan sinkretisme, di mana dalam sinkretisme dua atau lebih budaya yang berpadu tidak mengandaikan posisi dominan-subordinat.

Dalam pergesekan antara dua ranah budaya, hibrid lahir sebagai kompromi atas politik masa kolonialisme dan keterikatan dengan tradisi pribumi. Hibriditas menjadi penanda produktivitas kekuasaan kolonial sekaligus pergeseran kekuasaan dan kestabilan (Bhabha dalam Lym, 2006). Kehadirannya hibrid juga merupakan suatu bentuk evaluasi dan tantangan atas dominasi identitas kolonial yang berlaku. Dengan menjadi hibrid tidak lagi merujuk pada represi secara negatif dan materialis kolonisasi melainkan mengangkat serangkaian hubungan-hubungan ideologis yang kompleks dan ambigu.

Lebih lanjut Homi Bhaba (dalam Antariksa, 2000) mengajukan konsep mimikri untuk menggambarkan proses peniruan/peminjaman berbagai elemen kebudayaan. Menurutnya mimikri tidaklah menunjukkan ketergantungan sang terjajah kepada penjajah, ketergantungan kulit berwarna kepada kulit putih, tetapi peniru menikmati/bermain dengan ambivalensi yang terjadi dalam proses imitasi. Ini terjadi karena mimikri selalu mengindikasikan makna yang "tidak tepat" dan "salah tempat", ia imitasi sekaligus subversi. Dengan begitu mimikri bisa dipandang sebagai strategi menghadapi dominasi. Seperti penyamaran, ia bersifat ambivalen, melanggengkan tetapi sekaligus menegasikan dominasinya. Inilah dasar sebuah identitas hibrida.

Berdasar pemaparan tersebut dapat diketahui bahwa teori poskolonial berupaya untuk mengungkap efek-efek dari kolonialisme dalam teks sastra. Efek-efek kolonialisme dalam teks sastra dapat ditemukan dengan memanfaatkan pendekatan struktural untuk membedah teks sastra, terutama melalui latar dan tokoh. Sebab

Dalam pergesekan antara dua ranah budaya, hibrid lahir sebagai kompromi atas politik masa kolonialisme dan keterikatan dengan tradisi pribumi. Hibriditas menjadi penanda produktivitas kekuasaan kolonial sekaligus pergeseran kekuasaan dan kestabilan 
yang kuat pada efek-efek kolonialisme. Data-data yang dihasilkaan kemudian dikontraskan dengan wacana kolonialisme dan fakta-fakta yang terjadi di masa kolonialisasi.

\section{METODE PENELITIAN}

Penelitian ini merupakan penelitian kepustakaan (library research) dengan metode penelitian kualitatif. Langkah kerja penelitian novel Keroncong Cinta karya Ahmad Faishal terdiri dari tahap pemilihan dan pemahaman objek,pengumpulan data, dan analisis. Objek yang dijadikan penelitian adalah novel berjudul Keroncong Cinta karya Ahmad Faishal, cetakan pertama setebal 224 halaman, diterbitkan oleh Grasindo tahun 2006. Novel ini adalah novel unggulan Sayembara Mengarang Novel Remaja 2006 yang diadakan Grasindo dan Radio Netherland Suara Indonesia (Ranesi).

Dalam tahap pengumpulan data terdapat dua jenis data, yaitu data primer dan data sekunder. Data primer yaitu data-data yang diambil dari teks Keroncong Cinta, dalam hal ini adalah datadata yang memunculkan pengaruh hibriditas yang dihasilkan oleh ambivalensi antara hubungan kolonialis dan pribumi terhadap karakter tokoh. Data sekunder yaitu data-data yang berupa tulisan dan buku-buku yang digunakan sebagai referensi dalam penelitian ini, meliputi teori dan wacana poskolonial, sejarah Indonesia dan Surabaya di akhir masa kolonial (awal abad XX), kebudayaan Indis. Selanjutnya data-data tersebut menjadi bahan untuk tahap analisis guna menemukan bentuk-bentuk hibriditas dalam karakteristik tokoh dan interpretasi terhadap hibriditas tokoh tersebut dengan memanfaatkan teori poskolonial.

\section{HASIL DAN PEMBAHASAN}

Berbeda dengan Prancis, Inggris, dan Spanyol, kedatangan Belanda ke Nusantara bukan menjalankan misi 'pengadaban' dunia Timur yang dianggap primitif, melainkan menjalankan misi perdagangan melalui VOC. Namun setelah VOC runtuh dan digantikan pemerintah Belanda pada abad ke-18, terjadi ekploitasi kekayaan dari Hindia Belanda untuk memberi keuntungan pada negara induk. Hal ini dapat diasumsikan bahwa secara resmi pemerintah Belanda menempatkan Hindia Belanda sebagai daerah koloni.

Pada masa tersebut konflik yang terjadi antara penjajah dan terjajah hanya pada persoalan ekploitasi hasl-hasil kekayaan, belum merambah pada wilayah budaya. Pemerintah memposisikan orang Belanda dengan budaya Eropanya sendiri, dan pribumi dengan budaya tradisionalnya sendiri. Akulturasi budaya terjadi karena sifat dari budaya pribumi sendiri. Hal ini sesuai dengan temuan Anderson (dalam Soekiman, 2000:14) yang menunjukkan kemampuan segolongan masyarakat pribumi dalam mengambil unsur-unsur budaya asing tanpa meninggalkan budaya tradisionalnya, khususnya suku Jawa yang memiliki open minded tolerance atau savoir vivre (lapang dada) dalam menanggapi kebudayaan asing yang hadir.

Kedatangan orang-orang Belanda ke Hindia Belanda mayoritas laki-laki, karena perjalanannya menempuh medan yang berat dan panjang. Menurut Triyana (2007) dari sini pula muncul bantal guling, bantal yang digunakan oleh kaum lelaki Belanda sebagai teman tidur mereka di Hindia. Tentu saja bantal guling tak lagi berfungsi sebagai teman tidur para meneer Belanda ketika tradisi memelihara perempuan pribumi sebagai gundik sudah dimulai. Gundik memang tak pernah dinikahi secara sah, namun mereka diharuskan melayani meneer Belanda itu sebagaimana layaknya seorang istri. Namun ada juga yang memang secara resmi menikahi wanita pribumi. Hasil perkawinan tersebut adalah orang-orang Indo. Inilah bibit awal terjadinya hibriditas. Sebab perkawinan tersebut berimbas terjadi percampuran budaya Barat-Timur, yang terjadi pada diri nyai, anaknya yang Indo, dan lelaki Belanda yang secara sah mengawini wanita pribumi. Dalam novel Keroncong Cinta, tokohtokoh yang memiliki latar belakang tersebut dialami oleh keluarga Robert Neiis, yang sekaligus menjadi fokus dari cerita.

Setelah Terusan Suez dibuka, banyak wanitawanita asli Belanda yang datang. Hal ini semakin memojokkan status pribumi dan menggeser status orang-orang Indo. Pada abad ke-20, masyarakat Jawa khususnya Surabaya dibagi menjadi tiga lapisan sosial hirearkis yang didasarkan atas penggolongan berbasis etnisitas sebagai hasil pemisahan yang dilakukan pemerintah kolonial Belanda sebagaimana tercantum dalam Regering Reglement (Noordjanah, 2004:10). Tiga lapisan tersebut meliputi (1) golongan Belanda dan orang-orang Eropa lainnya; (2) golongan Timur Asing, yang diisi oleh orang-orang Melayu, Cina, Arab, dan India; (3) golongan Pribumi. Sebelum adanya depresi ekonimi dunia, golongan Indo yang mendapat pengakuan dari sang ayah yang 
Eropa masuk dalam golongan Eropa. Namun setelah adanya depresi ekonomi dunia, yang berimbas pada penggolongan beradasar ras yang lebih mendetail, orang-orang Indo masuk pada golongan kelas ketiga. Taylor Sraap dan Melissa van Scheltet merupakan representasi dari golongan Indo dalam Keroncong Cinta yang dianggap hina oleh kalangan Belanda totok, bahkan dianggap sama seperti pribumi.

Sementara itu, Kartodirdjo (dalam Soekiman, 2000:24) membagi masyarakat Hindia Belanda sebagai dampak perkembangan pendidikan dan pengajaran yang menumbuhkan golongan sosial baru yang mempunyai fungsi dan status baru, sesuai dengan diferensiasi dan spesialisasi dalam bidang sosial-ekonomi dan pemerintahan. Stratifikasi masyarakat Hindia Belanda menurut Kartodirdjo adalah: (1) elite birokrasi yang terdiri dari Pangreh Praja Eropa dan Pangreh Praja Pribumi, (2) priyayi birokrasi termasuk priyayi ningrat, (3) priyayi profesional (priyayi dibagi dua, ada priyayi gedhe dan priyayi cilik), (4) golongan Belanda dan Indo yang secara formal masuk status Eropa dan mempunyai tendensi kuat untuk mengidentifikasikan diri dengan pihak Eropa, dan (5) orang kecil (wong cilik) yang tinggal di kampung.

Pembagian golongan tersebut juga berimbas pada pengaturan-prangaturan kebijakan yang berbeda antargolongan. Perbedaan tersebut meliputi perbedaan atas hak dan kewajiban yang sangat memojokkan pribumi. Hal inilah yang digambarkan dalam novel Keroncong Cinta, di mana perbedaan hak-hak tersebut memicu adanya gerakan-gerakan antikolonialisme. Hal ini tersebut sesuai dengan yang dilakukan oleh Taylor Scraap dalam novel Keroncong Cinta yang melawan kolonialisme di Hindia Belanda karena merasa Indo dan pribumi selalu dianggap remeh dan hina. Pada orang-orang yang memiliki dualitas identitas, semisal orang Indo dan nyai, menyebabkan terjadinya pergeseran status sosial dan ambigutas identitas. Pergerseran identitas terjadi pada Nyai Zubaida berupa kenaikan status, sedangkan pada Robert Neiis terjadi penurunan status, karena hasil perkawinan antar-ras.

Faktor lain yang menyebabkan terjadinya hibriditas adalah pendidikan. Pendidikan di Hindia Belanda dilakukan dalam rangka menerapkan Politik Etis. Politik Etis ini dicetuskan oleh C. T. Van Deventer sebagai pelunasan 'Hutang Kehormatan' pemerintah Belanda karena telah mengeksploitasi kekayaan Hindia Belanda untuk kepentingan negeri Belanda. Pendidikan ini secara tidak langsung juga memasukkan pola-pola kultural Barat. Orang-orang hasil dari pendidikan tesrebut dipekerjakan sebagai bawahan pemerintah Hindia Belanda, biasanya sebagai pegawai administrasi rendahan ataupun pangreh praja. Hal ini sesuai dengan prinsip Asosiasi yang mencita-citakan suatu masyarakat Indonesia di mana dua golongan yaitu Eropa dan Pribumi akan dapat hidup berdampingan di dalam masyarakat. Golongan pribumi yang telah mendapat pendidikan Barat akan dapat bekerjasama dengan golongan Eropa (Poesponegoro dan Notosusanto, 1992:61). Hal tersebut tampak pada proses 'pembaratan' yang dilakukan pada Taylor Scraap dan Melissa van Scheltet dengan menyekolahkan langsung ke Belanda.

Pendidikan ini juga menghasilkan kalangan baru, yang sering disebut sebagai priyayi baru. Menurut Soekiman (2000:26) priyayi baru ini yang menjadi masyarakat pendukung kebudayaan indis. Dalam pola kehidupannya, priyayi baru ini diharuskan menghadapi pola-pola kehidupan yang baru, yaitu pola-pola kehidupan masyartakat Barat. Priyayi baru inilah yang disebut sebagai tokoh hibrida, di mana ada percampuran kebudayaan Jawa yang membentuk kulturnya dari kecil dengan pola-pola kultural Barat setelah dia mendapat pendidikan. Menurut Frederick (1989:27) di Surabaya, masyarakat pribumi memandang bahwa priyayi ini sebagai masyarakat yang eksklusif, yang bertempat tinggal di daerah elit. Terdapat jarak sosial antara kedua golongan ini yang tampak dari penggunaan bentuk-bentuk panggilan, di mana rakyat merasa diharuskan menggunakan panggilan yang menhormat seperti gus, den, atau jeng. Sebaliknya priyayi tidak menunjukkan penghormatan kepada mereka. Peristiwa ini dalam novel Keroncong Cinta terlihat dari pandangan Nyai Zubaida terhadap pribumi.

Pendidikan, dampak depresi ekonomi dunia, dan semakin banyaknya ras Eropa yang datang ke Hindia Belanda, membuat posisi Indo semakin tersingkir dari golongan Eropa. Menurut Gouda (2007:301) kelompok sayap kanan totok mulai memandang para Indo sebagai kelompok sosial yang menyusahkan dan tidak jelas identitasnya. Pendapat Gouda tersebut dilatarbelakangi oleh dampak depresi ekonomi dunia yang juga berimbas pada ekonomi Hindia Belanda. Masyarakat Indo mereaksi kondisi ini dengan mengatakan bahwa mereka memiliki hak moral atas tanah kelahiran mereka dari pada orang-orang Belanda totok 
yang datang (Gauda, 2007:302). Hal inilah yang mendasari munculnya rasa nasionalisme Taylor Scraap terhadap Hindia Belanda, karena ia dilahirkan di Hindia Belanda. Sikap nasionalisme ini diwujudkan dengan sikap antikolonialisme dan upaya untuk membentuk sebuah bangsa baru yang terlepas dari dominasi kolonial.

Selanjutnya, di awal abad ke-20 banyak berdiri perkumpulan-perkumpulan pemuda yang antikolonialisme. Perkumpulan ini seringkali dimotori oleh kaum terpelajar, baik dari pribumi maupun orang Indo, seperti Indische Partij, Boedi Utomo, dan Sarekat Islam. Para pemuda ini menuntut adanya kebijakan baru sebagai imbas kegagalan penerapan Politik Etis.

Pergantian kepemimpinan di Hindia Belanda di sekitar tahun 1930-an menyebabkan munculnya kebijakan baru yang disebut Politik Reaksioner. Politik Reaksioer diterapkan pemerintah Hindia Belanda untuk mengawasi secara ketat gerakangerakan pemuda antikolonialisme. Poesponegoro dan Notosusanto (1992:87) mengatakan bahwa politik de Jonge juga menciptakan peraturan Toezicht ordonantie (Ordonansi Pengawasan) pada 1 Oktober 1932 yang menolak ijin untuk menyelenggarakan pengajaran apabila dipandang membahayakan ketertiban masyarakat. Politik Reaksioner tersebut menghentikan beberapa kegiatan, sehingga gerakan-gerakan dilakukan secara sembunyi-sembunyi. Dalam novel Keroncong Cinta gerakan sembunyi-sembunyi ini dilakukan dengan menggunakan pementasan musik keroncong. Hal ini tampak pada kutipan berikut, "Saya sudah bicara banyak dengan Haji Anwar, dan dia merelakan kalau kelompok keroncong ini kita jadikan satu strategi khusus untuk mengecoh pengintaian pemerintah Hindia" (Faishal, 2006:74)

Dari pemaparan tersebut dapat diketahui kemunculan hibriditas di Hindia Belanda disebabkan sekurang-kurangnya empat faktor, yaitu (1) perkawinan antara Belanda-Pribumi; (2) pergundikan; (3) pendidikan, dan (4) semangat meraih persamaan derajat dari orang-orang Indo. Faktor-faktor tersebut juga menjadi latar belakang hibriditas yang dialami tokoh-tokoh dalam novel Keroncong Cinta. Hibriditas Robert Neiis disebabkan karena perkawinannya dengan Nyai Zubaida, seorang pribumi; Nyai Zubaida sendiri hibriditasnya dilatarbelakangi faktor pergundikan; sedangkan Taylor Scraap dan Melissa van Scheltet disebabkan oleh pendidikan dan semangat meraih persamaan derajat dengan Eropa.

\section{Bentuk-bentuk Hibriditas Tokoh dalam Novel Keroncong Cinta}

\section{A. Ambiguitas Identitas Taylor Scraap}

Dengan adanya penyusunan hirearki sosial berdasar warna kulit, masyarakat Indo berada pada wilayah 'antara' dan ambivalen. Hal ini seperti diungkapkan Mangunwijaya (dalam Hunter 2006:149) bahwa masyarakat Indo adalah masyarakat yang dalam penghayatan realitas hidup dan kebudayaannya terbelah, bahkan alienated, setengah asing terhadap diri sendiri, apalagi situasi dan keadaan sekelilingnya. Hal inilah yang memicu munculnya hibriditas masyarakat Indo. Kondisi tersebut dialami oleh tokoh-tokoh Indo dalam novel Keroncong Cinta, yaitu Taylor Scraap dan Melissa van Scheltet. Hibriditas Taylor Scraap tampak pada kondisi psikologisnya yang ambivalen di tengah pemerintahan Hindia Belanda.

Hibriditas Taylor Scraap bermula dari pembentukan pola pikir Eropa yang dilakukan orangtuanya. Taylor Scraap, sebagai orang indo, secara otomatis memiliki darah Jawa dari ibunya. Dengan memiliki darah orang Jawa dan dilahirkan di Hindia Belanda, maka sekecil apapun terdapat pengaruh budaya pribumi padanya. Pandangan Bibi Tija dan Nyai Zubaida terhadap sosok Taylor Scraap yang lebih mewarisi darah Jawa, dan lebih memilih bergaul dengan orang-orang pribumi, memberikan keterangan adanya pengaruh pribumi terhadap pembentukan diri Taylor Scraap. Pendidikan Taylor Scraap di negeri Belanda bertujuan untuk meminimalkan perkembangan pengaruh budaya pribumi.

Pola pendidikan yang dilakukan kedua orang tuanya tersebut merupakan upaya untuk mempertahankan status ke-Eropa-annya. Selain faktor warna kulit, pendidikan pada masa Hindia Belanda merupakan salah satu faktor yang mempengaruhi mobilisasi status sosial. Pendidikan dianggap sebagai alat untuk dapat memasuki lingkungan hidup baru, hidup kepriyayian, bagi golongan bawah, dan penambah legitimasi bagi golongan atasan.

Pendidikan Taylor Scraap menempatkannya pada status yang mendekati status tertinggi masyarakat Hindia Belanda. Hal ini tampak pada penyebutan 'tuan' oleh Darmaji (Faishal, 2008:74). Penyebutan Taylor Scraap dengan memakai 'tuan' bukan sekedar sebuah penghromatan, namun menunjukkan bahwa tingkatan status sosial Taylor Scraap dipandang lebih tinggi oleh Darmaji. Darmaji sendiri adalah seorang pribumi 
yang memiliki pendidikan tinggi. Dengan demikian dapat ditarik kesimpulan bahwa kedudukan Taylor Scraap jauh lebih tinggi dari pribumi biasa. Hal ini juga diperjelas dengan kedekatan keluarga Taylor Scraap dengan pemerintah Hindia Belanda.

Menurut Bhaba (dalam Sutrisno dan Putranto, 2004:28) hibriditas merupakan produk konstruksi kultural kolonial yang mau tetap membagi strata identitas murni asli penjajah dengan ketinggian kultur yang didiskriminasikan dengan kaum campuran indo. Berdasar asumsi tersebut, dapat dikatakan bahwa Taylor Scraap merupakan produk konstruksi kultural kolonial, dimana pola-pola pikir Eropa dimasukkan melalui pendidikan langsung di Belanda. Tetapi fakta bahwa Taylor Scraap memiliki darah Jawa (pribumi) dan dilahirkan di wilayah koloni, menjadikan munculnya ambivalensi identitas pada diri Taylor. Ambivalensi identitas Taylor Scraap dapat dilihat dari perkataan Jenderal L. S Covet, “Percuma kamu sekolah ke negeri Belanda jika hanya menentang Pemerintah Hindia Belanda." Kutipan tersebut juga menerangkan bahwa status sosial Taylor Scraap masih di bawah status Eropa.

Pendidikan di negeri Belanda pada satu sisi menanamkan kultur-kultur Eropa, namun di lain pihak juga memberikan wacana-wacana lain yang bertentangan dengan ideologi kolonialis. Pendidikan di Belanda juga memberikan kesadaran bahwa 'cita-cita mulia' kolonialisasi untuk membawa daerah-daerah koloni pada peradaban modern telah menyimpang. Bagi kalangan Indo yang dilahirkan di Hindia Belanda, kondisi tersebut menumbuhkan beban historis berupa rasa bersalah atas perlakukan lelulur mereka pada pribumi. Hal inilah yang menyebabkan munculnya perasaan senasib dengan pribumi pada diri Taylor Scraap. Adanya persamaan nasib dengan pribumi sebagai golongan terjajah nampak pada kutipan berikut.

Kita, orang keturunan, juga orang pribumi berada pada posisi yang sangat tidak beruntung. Kita selalu dianggap hina. Kita berkumpul di sini untuk suatu tawaran pada pemerintah dan juga sedikit menyamakan hak atas pendidikan dan sebagainya." (Faishal, 2006:17)

"Dengar, Pa. Orang-orang Belanda sudah terlalu kejam dan berlebihan pada orang pribumi. Orang-orang Belanda juga memandang sebelah mata pada orang keturunan." Taylor mengucapkan kata-katanya dengan nada tinggi dan emosional. Amarah Taylor memang sedang meninggi sejak seharian sehingga Robert Neiis merasa kaget dengan intonasi Taylor, karena tidak seperti biasanya Taylor mengucapkan kata-kata dengan nada tinggi di dalam rumah." (Faishal, 2006:97)

Taylor kemudian diam beberapa saat., "Ya. Asia Timur Raya yang didengungkan Jepang itu pasti sejalan dengan pikian kita. Mereka terang-terangan menolak kekuasaan Eropa." (Faishal, 2006:196)

Dari kutipan-kutipan tersebut, tampak bagaimana perasaan senasib dengan pribumi serta pandangan Taylor Scraap terhadap praktek kolonialisasi. Pandangan tersebut merupakan kritik bahwa misi pengadaban dunia Timur hanyalah pengukuhan akan supeririotas Barat. Inilah yang menjadikan Taylor Scraap menganggap bahwa kultur Barat tidak memenuhi nilai-nilai kemanusiaan.

Dalam wacana kolonial, menurut Bhaba (dalam Lim, 2006) hibriditas mengacu pada suatu problema representasi dan individuasi kolonial, yang membalikkan dampak-dampak penyangkalan kolonial, sedemikian rupa sehingga pengetahuan lain yang disangkal meresap kedalam wacana dominan dan mengasingkan pijakan kewenangannya-kaidah pengakuannya. Pada diri Taylor Scraap, keadaan ini membutanya mengalami keterpecahan psikologis, dimana di satu pihak meski menjaga citra keluarganya yang memiliki kedekatan dengan pemerintah Hindia Belanda, tetapi di lain pihak meski menentang kolonialisasi karena kenyataan secara genetik Taylor Scraap adalah bagian dari yang terjajah. Kondisi Taylor Scraap ini oleh Loomba (2003:179) disebut sebagai pelanggaran terhadap identitasidentitas kelompok yang telah diterapkan, atau sering disebut sebagai dekulturasi. Produk kultural dan pola pikir Eropa yang dibentuk oleh keluarganya hanya menjadi 'topeng putih' dalam menghadapi superioritas kolonialis.

Sebagai puncak dari ambiguitasnya, Taylor Scraapmenjadisosokpribadiyangantikolonialisme, dan mengupayakan kemerdekaan Hindia Belanda. Cita-cita membentuk suatu pemerintahan sendiri bagi pribumi adalah upaya untuk meminimalisir beban-beban psikologis yang ada dalam pikiran Taylor Scraap. Taylor Scraap mengukuhkan diri secara imanen sebagai seorang pribumi. Tetapi adanya revolusi fisik dari Jepang, identitas Taylor 
Scraap kembali mengalami ambiguitas. Revolusi fisik Jepang dengan dikotomi Barat-Timur berdasarkan ras, menempatkan orang-orang Indo dalam wilayah Barat.

\section{B. Kesadaran Melissa van Scheltet sebagai Kelas Ketiga}

Dalam kontradiksi kultural antara barat dan timur, Melissa van Scheltet sejak awal memiliki pandangan bahwa ras Eropa di Hindia Belanda superior atas pribumi. Seperti yang dikutip berikut ini:

[...] Melisa membayangkan jika seandainya Qomar memiliki tanah yang luas atau memakai baju Eropa, tentu dia akan menjadi angkuh dan dikerumuni gadis-gadis, tapi sayang Qomar memiliki jalan yang lain. (Faishal, 2006:10)

Kutipan tersebut secara tidak langsung menggambarkan konstruksi golongan Eropa menurut pandangan Melissa van Scheltet. Pandangan ini merupakan produk dari sistem kolonialisasi dan doktrin-doktrin orang tuanya. Inilah upaya penciptaan identitas Eropa pada diri Melissa van Scheltet. Seperti halnya Taylor Scraap, sebagai seroang indo, Melissa van Scheltet memperoleh nilai-nilai kultural Eropa secara lebih mendalam melalui pendidikan langsung di Belanda. Bagi seorang wanita indo, pendidikan merupakan sebuah keniscayaan untuk memperoleh kedudukan yang setara dengan ras Eropa.

Perilaku-perilaku yang merujuk pada kultural Eropa ditunjukkan melalui pemilihan busana Melissa yang bergaya Eropa (Faishal, 2006:101101;103), serta kegiatan-kegiatan yang mengikuti Robert Neiis. Hal ini sesuai dengan pernyataan Gouda (2007:285) tanda-tanda dan simbolsimbol kelas tanpa disadari terartikulasi dalam penampilan busana, gaya, dan tuturan. Sampai pada tahapan ini, pembentukan karakter diri Melissa van Scheltet berkultur Eropa mencapai titik puncak. Namun sebenarnya identitas keEropa-an Melissa van Scheltet hanyalah sebuah kamuflase, sebab pembentukan tersebut bukan murni berasal dari kesadaran Melissa sendiri sebagai subyek yang terdiskriminasi kolonial, melainkan pembentukan tersebut adalah hasil campur tangan orang tuanya.

Ambivalensi identitas diri Melissa muncul sebagai reaksi atas perkataan Sarrah von Condomme bahwa derajat dan status hanya bisa dilihat dari ras dan darah, bukan melalui faktorfaktor lainnnya seperti pendidikan yang dilakukan oleh orang pribumi maupun keturunan (Faishal, 2006:109). Perkataan Sarrah von Condomme tersebut setidak-tidaknya memiliki dua maksud, pertama menujukkan bahwa orang-orang Belanda totok menduduki kelas teratas pada stratifikasi sosial Hindia Belanda yang apartheid. Kedua menunjukkan bahwa menjadi Eropa bagi Indo dan pribumi adalah suatu kemustahilan.

Dari peristiwa inilah hibriditas Melissa van Scheltet hadir. Kesadaran akan fakta biologis di dirinya memunculkan kesadaran akan ambiguitas identitasnya sekaligus kesadaran bahwa dirinya berada pada kelas ketiga. Hal tersebut tampak pada kutipan berikut.

\section{[...] Tiba-tiba Melissa berdiri} dan menghadap ke cermin, ia terus memandangi rambutnya yang terurai. Melissa terus memerhatikan setiap detail raut wajahnya. Mata, hidung, alis, pipi, bibir, kulit, rambut, gigi, dan sebagainya. ia mulai sedikit membenci organ-organ tersebut. (Faishal, 2006:109-110).

Kesadaran tersebut juga menumbuhkan keterasingan Melissa van Scheltet sebagai Indo akan posisinya secara identitas maupun kultural. Ambiguitas identitas ini memuncak pada kerapuhan psikologis Melissa van Scheltet sebagai pribadi Eropa yang telah ia rasakan sebelumnya. Dalam konteks kolonialisme, Melissa van Scheltet mengalami ketidakmapanan identitas, yang merupakan salah satu ciri sintesa hibrida.

Sebagai jalan keluar dari ambiguitas tersebut, Melissa mulai meninggalkan gaya berpakaian Eropa, serta membiasakan diri dengan kultur pribumi (Jawa) seperti memasak, bahkan dia bermutasi menjadi pribumi dengan mengawini Qomar yang secara sosial masuk dalam kelas pribumi. Dalam kontradiksi dua kutub tersebut, plihan Melissa van Scheltet bermutasi menjadi pribumi mengantarkannya pada kejelasan posisi dan status dalam lingkungan kolonial.

\section{Ikatan Emosional Robert Neiis pada Pribumi}

Meskipun konstruksi kultural Eropa telah terbentuk pada diri Robert Neiis, perkawinan dengan wanita pribumi sedikit banyak telah mempengaruhi pola hidupnya. Menurut Shahab 
(2004) bahwa orang-orang Eropa yang mengawini Pribumi cenderung kehilangan ciri-ciri Eropa tertentu dan mengambil berbagai gaya hidup pribumi. Hal-hal seperti kesukaanya terhadap maskan-masakan Jawa (Faishal, 2006:8) menjadi bagian dari dirinya, menjadi bagian dari identitas hibridanya.

Memang perkawinan tersebut tidak terlalu mempengaruhi identitas ke-Eropa-annya apalagi Robert Neiis memiliki latar belakang kedekatan dengan pemerintah Hindia Belanda. Namun jika ditinjau dari segi terdalam dirinya, dari segi emosionalnya, Robert Neiis menjelma sebagai tokoh hibrida yang mengaburkan garis-garis antagonisme antara penjajah dan terjajah. Hal tersebut tampak pada kutipan berikut.

Taylor menyambut pertanyaan Robert Neiis dengan senyum kecut. "Saya tahu apa yang Papa sembunyikan selama ini, saya tahu hati kecil Papa juga berpikiran sama seperti saya. Tapi sayang, pikiran-pikiran Papa tidak pernah dibuka dan diekspresikan, karena Kakek termasuk orang penting di lingkungan pemerintah kolonial, kan? Saya yakin Papa juga sayang pada keluarga lbu dan Papa tak hendak kembali ke Belanda, tapi, Papa takut untuk mengutarakannya, karena Papa ..." (Faishal, 2006:98)

Pengaburan garis-garis kontradiktif dua kultural tersebut merupakan sebuah untuk melepaskan diri dari konflik batin. Robert Neiis memilih jalan aman dengan tidak menentang pemerintah Hindia Belanda sekaligus tidak menempatkan pribumi sebagai subyek yang inferior. Hal ini disebabkan adanya percabangan emosional, dimana satu kaki berada di wilayah Eropa, dan kaki satunya bersinggungan dengan wilayah pribumi.

\section{Transformasi Kultur Eropa pada Nyai Zubaida}

Kisah nyai-nyai yang berlangsung pada dua abad lalu ini menjadi jamak karena orang Belanda dan Cina yang tiba di Batavia saat itu sering tanpa istri. Mereka mengawini wanita pribumi atau mengambil nyai (gundik), terutama dari kalangan budak (Shahab, 2004). Perkawinan inilah yang menjadi faktor utama terjadinya hibriditas yang mengakibatkan terjadinya mobilisasi status sosial. Dalam teks Keroncong Cinta Nyai Zubaida menjadi tokoh yang paling representatif untuk menggambarkan hibriditas seorang nyai.

Nyai Zubaida, seorang pribumi yang dikawini oleh Robert Neiis, mendapatkan tranformasi kultural Eropa pada dirinya melalui campur tangan Robert Neiis. Pandangan-pandangan Nyai Zubaida yang teramat mengagungkan superioritas Eropa atas pribumi. Orientasi ke-Eropa-an Nyai Zubaida ditunjukkan melalui nasehatnya pada Melissa van Scheltet karena perempuan memiliki kelemahan secara fisik, maka hendaknya perempuan memiliki kecerdasan (Faishal, 2006:10). Konsepsi tentang perempuan tersebut merupakan konsepsi khas Barat yang bertentangan dengan konsepsi perempuan Jawa di waktu dulu. Perempuan Jawa tidak memerlukan pendidikan yang tinggi, karena kultur Jawa mengajarkan bahwa secerdas apapun otaknya tetap saja takdirnya dalah urusan dapur.

Penyerapan nilai-nilai Eropa dari
perkawinannya mengakibatkan terjadinya kamuflase identitas pada diri Nyai Zubaida. Di satu sisi reduplikasi identitas Eropa pada diri Nyai Zubaida tidak tercapai secara maksimal. Sikapnya yang terlalu mengagungkan Eropa, seperti ketika berusaha menyuruh Melissa memakai pakaian khas Eropa untuk menemu Frederik L. S. Covet, secara tidak langsung menunjukkan inferioritas Nyai Zubaida terhadap Eropa. Tetapi di sisi lain Nyai Zubaida merasa memiliki kelas yang jauh lebih tinggi dari pribumi. Hal ini berarti Nyai Zubaida bereformasi ke dalam kelas ras sebagaimana diistilahkan Bhaba (dalam Tickell, 2006:68) sebagai kelas ketiga, sebagai subyek perbedaan yang nyaris sama, tapi tidak begitu sama. Maka menjadi sebuah kewajaran jika Nyai Zubaida memiliki pandangan-pandangan yang diskriminatif terhadap pribumi. Seperti yang dikutip berikut ini.

"Semakin dewasa, kerjamu semakin tidak karuan, Qomar. Rupanya kamu memanfaatkan kebaikan dan keakrabanmu dengan Taylor. Meskipun sejak kecil kamu berada di sini, derajatmu tidak akan berubah dari seorang budak." (Faishal, 2006:42)

"Apa?" Nyai Zubaida membelalakkan mata, "Dia memang baik karena dia seorang pembantu. Dia tidak punya masa depan, hidupnya selalu tergantung pada orang lain. Apa kamu lupa bahwa dia hanya seroang pembersih kaca!" (Faishal, 2006:186)

Perilaku Nyai Zubaida pada Qomar bukan semata-mata perilaku tipikal seorang majikan, tetapi menunjukkan bahwa kelas sosial antara keduanya berbeda. Pada bagian ini tampak adanya penolakan terhadap status ke-pribumi-an yang melekat pada diri Nyai Zubaida. Perilaku ini sesuai 
dengan pendapat Soekiman (2000:36) dengan membanggakan sebuah budaya, dalam hal ini budaya Barat untuk mengejar prestise dalam hidup masyarakat kolonial.

Perlu diperhatikan juga bahwa Nyai Zubaida tidak sepenuhnya meninggalkan kultur pribuminya (Jawa) yang tampak pada pemilihan pakaiannya dengan tetap menggunakan kebaya. Adanya percampuran antara dua kultur yang berbeda ini, dimana secara visual tampak kultur Jawa tetapi memiliki pandangan-pandangan yang kebarat-baratan, semakin menegaskan adanya identitas yang tidak menentu. Foulcher (2006:199) menyebutnya sebagai identitas-identitas tambal sulam yang semakin tidak menentu.

\section{SIMPULAN}

Berdasarkan penelitian tersebut, dapat dibuktikan bahwa sastra remaja, sebagai bagian dari sastra populer, tidak hanya berisi tentang hiburan, kesederhanaan, dan persoalanpersoalan yang ringan. Mengenai hal tersebut, novel Keroncong Cintamenunjukkan dengan menghadirkan kembali cerita tentang kolonialisasi danmenampilkan tokoh-tokoh hibrida. Bentukbentuk hibriditas yang dialami oleh tokoh-tokoh dalam novel Keroncong Cinta merupakan salah satu dampak dari kolonialisme Belanda di Hindia Belanda. Bentuk-bentuk hibriditas tersebut antara lain ambiguitas identitas dan kesadaran orang Indo sebagai kelas ketiga; pengaburan garis-garis kontradiktif koloniaslisme; dan orientasi ke-Eropaan seorang Nyai.

\section{Daftar Pustaka}

Antariksa. 2000. :Identitas Hibrida". Dalam Kunci no. 6-7, Mei-Juni 2000. Http://rinangxu. wordpress.com/2007/03/09/identitas-hibrida/.

Barker, Chris. 2005. Cultural Studies: Teori dan Praktik. Yogyakarta: Bentang.

Faishal, Ahmad. 2006. Keroncong Cinta. Jakarta: Grasindo.

Foulcher, Keith dan Tony Day. 2006. Clearing A Space: Kritik Tentang Sastra Indonesia Modern. Jakarta: Yayasan Obor Indonesia.

Frederick, William H. 1989. Pandangan dan Gejolak: Masyarakat Kota dan Lahirnya Revolusi Indonesia (Surabaya 1926-1946). Jakarta: Gramedia.

Gouda, Frances. 2007. Dutch Culture Overseas: Praktik Kolonial di Hindia Belanda, 1900-1942. Jakarta: Serambi.

Gandhi, Leela. 2006. Terori Poskolonial: Upaya Meruntuhkan Hegemoni Barat. Yogyakarta: Qolam.

Gelder, Ken. 2004. Popular Fiction: The Logics and Prctices of a Literary Field. New York: Routledge.

Heryanto, Ariel. 1984. "Masihkah Politik Menjadi Panglima? Permasalahan Kesusastraan Indonesia Mutakhir". Dalam Prisma nomor 8 tahun XVII. Jakarta: LP3ES.

Hunter, Thomas. 2006. "Indo sebagai Other: Identitas, Kecemasan, dan Ambuguitas dalam Salah Asiuhan." Dalam Keith Foulcher dan Tony Day (ed), Clearing A Space: Kritik Tentang Sastra Indonesia Modern. Jakarta: Yayasan Obor Indonesia.

Kayam, Umar. 1981. Seni, Tradisi, Masyarakat. Jakarta: Sinar Harapan.

Loomba, Ania. 2003. Kolonialisme/Postkolonialisme. Yogyakarta: Bentang.

Lym, Marilyn. 2006. "Hibriditas dalam Arsitektur Kolonial". Alambina. Juni 19.Http://www. alambina.net/?phpzap=news\&part=detail\&id_news=40\&lang=id.

Noordjanah, Andjarwati. 2004. Komunitas Tionghoa di Surabaya (1910-1946). Semarang: Messias.

Poesponegoro, Marwati Djoenet dan Nugroho Notosusanto. 1992. Sejarah Nasional Indonesia V. Jakarta: Balai Pustaka.

Shahab, Alwi. 2004. "Dasima dan Kisah Para Nyai". Republika, Januari 04.

Soekiman, Djoko. 2000. Kebudayaan Indis dan Gaya Hidup Masyarakat Pendukungnya di Jawa. Yogyakarta: Yayasan Bentang Budaya.

Salam, Aprinus. 2002. "Posisi Fiksi Populer di Indonesia".Dalam Jurnal Humaniora Volume XIV no. 2. Yogyakarta: Universitas Gadjah Mada.

Sumarjo, Jakop. 1982. Novel Populer Indonesia. Yogyakarta: Nur Cahaya.

Sutrisno, Mudji dan Hendar Putranto. 2004. Hermeneutika Pascakolonial: Soal Identitas. Yogyakarta: Kanisius.

Triyana, Bonnie. 2007. "Skandal Seks Meneer Montigny di Rangkasbitung". Dalam mail-archive. com/wongbanten@yahoogroups.com/msg05277.html. 